\title{
Characterization of the Etna volcanic emissions through an active biomonitoring technique (moss-bags): Part 2 - Morphological and mineralogical features
}

\author{
S. Calabrese ${ }^{\mathrm{a}, *}$, W. D'Alessandro ${ }^{\mathrm{b}}$ \\ a Dipartimento di Scienze della Terra e del Mare (DiSTeM), Università degli Studi di Palermo, via Archirafi 36, 90123 Palermo, Italy \\ ${ }^{\mathrm{b}}$ Istituto Nazionale di Geofisica e Vulcanologia (INGV), Sezione di Palermo, via La Malfa 153, 90146 Palermo, Italy
}

\section{H I G H L I G H T S}

- First study of volcanic particles characterization by using moss-bags.

- Atmospheric deposition on Mt. Etna is dominated by volcanogenic and geogenic input.

- A huge amount of silicates, sulfates and halides are continuously emitted from Etna.

- The polygenic particles testify overgrowing processes that occur inside the plume.

\section{A R T I C L E I N F O}

\section{Article history:}

Received 8 October 2013

Received in revised form 5 August 2014

Accepted 18 August 2014

Available online 11 October 2014

Handling Editor: X. Cao

\section{Keywords:}

Volcanic aerosols

Plume

Passive degassing

Sphagnum

Sulfates

\begin{abstract}
A B S T R A C T
Volcanic emissions were studied at Mount Etna (Italy) by using moss-bags technique. Mosses were exposed around the volcano at different distances from the active vents to evaluate the impact of volcanic emissions in the atmosphere. Morphology and mineralogy of volcanic particulate intercepted by mosses were investigated using scanning electron microscopy (SEM) equipped with energy dispersive spectrometer (EDS). Particles emitted during passive degassing activity from the two active vents, Bocca Nuova and North East Crater (BNC and NEC), were identified as silicates, sulfates and halide compounds. In addition to volcanic particles, we found evidences also of geogenic, anthropogenic and marine spray input. The study has shown the robustness of this active biomonitoring technique to collect particles, very useful in active volcanic areas characterized by continuous degassing and often not easily accessible to apply conventional sampling techniques.
\end{abstract}

(c) 2014 Elsevier Ltd. All rights reserved.

\section{Introduction}

Active volcanoes represent one of the most important natural sources of gases and particles to the atmosphere, both during and between eruptive periods. Volcanic emissions may exert a deleterious impact on the surrounding environment and on human health (Delmelle, 2003), often displaying strong similarities with emissions from high temperature anthropogenic processes (transport, electric energy production, ore smelting, etc.). The often highly toxic trace metals (and metalloids) belong to these potentially deleterious emissions (Sekine et al., 2008).

Volcanogenic aerosols continuously injected into the atmosphere exert a strong impact on the chemistry of the troposphere:

\footnotetext{
* Corresponding author.

E-mail address: sergio.calabrese@gmail.com (S. Calabrese).
}

estimates indicate that $18-40 \%$ of the global tropospheric sulfate burden is derived from volcanism (Chin and Jacob, 1996; Graf et al., 1998). Among the presently active volcanoes Mount Etna is one of the most prodigious and persistent source of gases and particles to the troposphere. Previous estimates confirm that Mt. Etna is one of the major volcanic gas emitters on Earth, accounting for about $1.6 \%$ of global $\mathrm{H}_{2} \mathrm{O}$ fluxes from arc volcanism (Aiuppa et al., 2008) and $10 \%$ of global average volcanic emission of $\mathrm{CO}_{2}$ and $\mathrm{SO}_{2}$ (D'Alessandro et al., 1997; Caltabiano et al., 2004). Mt. Etna is also an impressive source of volcanic particles (Gauthier and Le Cloarec, 1998), and the mass flux of particle (including potentially toxic trace elements, e.g. $\mathrm{As}, \mathrm{Bi}, \mathrm{Cd}, \mathrm{Cu}, \mathrm{Sb}, \mathrm{Se}, \mathrm{Tl}$ ) passively released from the volcano during non-eruptive period has been recently estimated to range from 7 to 23 tons per day (Martin et al., 2008; Calabrese et al., 2011). Moreover, the active craters are located at more than $3000 \mathrm{~m}$ of altitude and the 
emissions are directly released in the free atmosphere above the boundary layer. Thereafter, only a small fraction (about $0.1-5 \%$ ) of the volcanogenic emissions is re-deposited close to the volcano, as previously discovered both for major (Aiuppa et al., 2006) and trace elements (Calabrese et al., 2011).

The moss-bags technique has been extensively used in the past 40 years as an efficient tool to monitor atmospheric pollutants. This active biomonitoring technique has been often used to evaluate distribution of pollutants released by human activities in industrial and/or urban areas (Adamo et al., 2007; Tretiach et al., 2007). The same technique has been successfully applied also in volcanic environments (Arndt et al., 2014; Calabrese et al. 2014). Many biomonitoring studies were carried out on Mount Etna, due to the suitable condition for sampling and monitoring the dispersion of volcanogenic species (Notcutt and Davies, 1989; Martin et al., 2009, 2012; Quayle et al., 2010). In a companion paper (Calabrese et al., 2014) we demonstrated the applicability and the robustness of the moss-bags technique to characterise the emission and dispersion of trace elements in an active volcanic area like that of Mount Etna. In the present paper we focused on the morphology (size and shape) and mineralogy (crystalline habitus, minerals assemblage, chemistry) of particles intercepted by the moss-bags exposed in different sites around the active degassing vents. For comparison, the results from an urban site (Catania) are also discussed.

\section{Previous studies}

The most common technique for sampling the volcanic particulate is the filtration of the bulk plume through a filter by using single stage collectors or cascade impactors to selectively collect particles of different size fractions. Total acid digestion and/or leaching of the filters allow to obtain chemical abundances of major and trace elements in the volcanic aerosols. Alternatively, the collected filters can be used for morphologic and qualitative chemical analysis of individual particles by using scanning or transmission electron microscopy (SEM or TEM), often coupled with energy-dispersive X-ray spectroscopy (EDS or EDX). Despite of the numerous logistical difficulties in sampling, previous authors have successfully adopted these techniques collecting and characterizing volcanic aerosols emitted from the active craters of Mount Etna. Lefevre et al. (1986) have estimated the concentration of silicate microspherules (mainly ranging from 0.1 to $2 \mu \mathrm{m}$ in diameter) as 3-7 million per cubic meter and a total output from Etna of 1.6 tons per day. In other subsequent studies (Varekamp et al., 1986; Toutain et al., 1995) a large number of volcanic particles including silicates, metal-rich sulfates, chlorides and oxides, have been identified and characterized (size, shape and chemical composition). Varekamp et al. (1986) discovered polygenic particles with evidence of multiphase history (overgrowths, reaction rims, corrosion). Andres et al. (1993) have highlighted the importance of the size-selective sampling to discriminate chemical composition of particles in relation with their size, by using a quartz crystal microbalance impactor (QCM). An innovative approach has been proposed in a recent paper by Martin et al. (2008), where an automated scanning electron microscopy (QEMSCAN) was used to determine size, shape and composition for a large number of particles in the Mount Etna plumes. They have recognized silicates, sulfate and sulfide species, of variable composition, and they have estimated an emission flux of $10^{18}$ silicate nanoparticles ( $<10 \mu \mathrm{m}$ in diameter) per second. An overview of the previous results in comparison with our study is showed in Table 3.

\section{Material and methods}

\subsection{Moss-bags preparation, exposure and collection}

For the preparation, exposure and collection of the moss-bags we used the methods described in the companion paper (Calabrese et al., 2014). In particular, samples of Sphagnum species (S. fuscum and S. tenellum) were collected in a clean rural area (Gothenburg, Sweden). The mixture of mosses was cleaned several times with MilliQ water to remove debris, particles and dead or
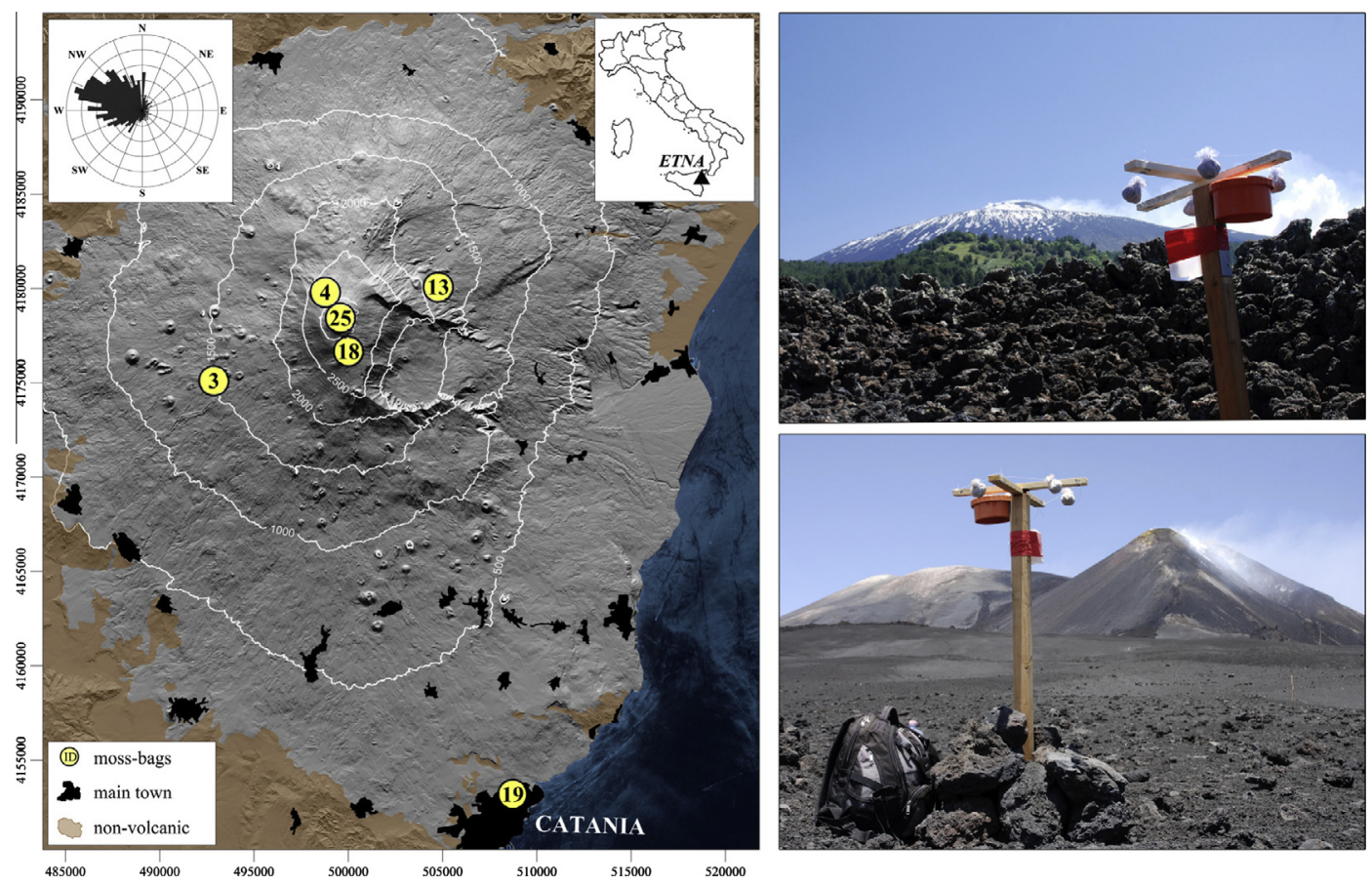

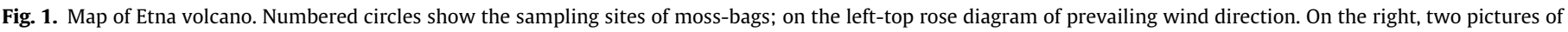
sampling sites: Mt. Intraleo (INT) on top and Torre del Filosofo (TDF) on bottom. 
Table 1

Sampling sites location.

\begin{tabular}{|c|c|c|c|c|c|c|c|c|}
\hline \multirow[t]{2}{*}{ ID } & \multirow{2}{*}{$\begin{array}{l}\text { Site } \\
\text { INT }\end{array}$} & \multirow{2}{*}{$\frac{\text { Location }}{\text { Mt. Intraleo }}$} & \multirow{2}{*}{$\begin{array}{l}\text { Description } \\
\text { Rural (up-wind) }\end{array}$} & \multicolumn{3}{|c|}{ Cordinate (UTM WGS84) } & \multirow{2}{*}{$\frac{\text { Altitude ( } \mathrm{m} \text { a.s.l.) }}{1510}$} & \multirow{2}{*}{$\frac{\text { Distance from craters }(\mathrm{km})}{7.5}$} \\
\hline & & & & $33 \mathrm{~S}$ & 492873 & 4175104 & & \\
\hline 4 & PLU & Punta Lucia & Summit (up-wind) & $33 \mathrm{~S}$ & 498779 & 4179800 & 2914 & 1.6 \\
\hline 13 & CIT & Citelli & Rural (down-wind) & $33 \mathrm{~S}$ & 504769 & 4180074 & 1750 & 5.4 \\
\hline 18 & TDF & Torre del Filosofo & Summit (down-wind) & $33 \mathrm{~S}$ & 500009 & 4176659 & 2905 & 1.8 \\
\hline 19 & CAT 2 & Catania & Urban & $33 \mathrm{~S}$ & 508716 & 4153172 & 53 & 26.9 \\
\hline 25 & VOR & Voragine & Active crater & $33 \mathrm{~S}$ & 499581 & 4178430 & 3280 & 0.0 \\
\hline
\end{tabular}

senescent parts, and dried at room temperature under a laminar hood. Approximately $2 \mathrm{~g}$ (dry weight) of moss was placed in commercial mosquito nylon net with $2 \mathrm{~mm}$ mesh size (previously washed with rinsing solution) forming sub-spherical bags. The survey was carried out in the summer 2007. Two of the 24 chosen sites were placed in the nearby city, Catania, while the remaining were placed on the upper flanks of the volcano. Most of the latter sites were placed downwind with respect to the summit craters, considering the prevailing wind direction. Moss bags were suspended $2 \mathrm{~m}$ above the ground with a wood pole (Fig. 1), and exposed for about one month. The location of the sites selected for particulates characterizations is shown in Fig. 1 and Table 1.

\subsection{SEM/EDS analysis}

The moss-bags, after their exposition, were transferred to the laboratory in sealed plastic containers. Three shoots, about $2 \mathrm{~mm}$ long, were separated from each selected moss-bag for microscope observations, carbon-coated within few days and stored in refrigerator until analysis. Morphology and mineralogy of particulates adhering on moss tissue were investigated by using Scanning Electron Microscopy (SEM-Oxford Leo 440) equipped with Energy Dispersive Spectrometry (EDS-Link ISIS). EDS semi-quantitative analyses were carried out to detect major chemical components of particles on mosses tissue. Operating conditions were $20 \mathrm{kV}$ accelerating voltage and $150-600 \mathrm{pA}$ beam current, while the acquiring area (spot size) was about $5 \mu \mathrm{m}$ in diameter. Samples for SEM/EDS analyses were selected from 6 sites whose characteristics are summarised in Table 1 . About 120 scanning electron images of moss samples were examined, and more than 200 EDS spectra were obtained from the particles trapped in the moss-bags. A summary of the results is listed in Table 2.

\section{Results and discussion}

\subsection{Morphological features of the mosses}

Moss leaves of non-exposed samples showed externally wellpreserved tissues and showed a particle-free surface (Fig. 2), while the ones of exposed samples (Figs. 3-6) were covered with particles of different size and shape. Scanning electron micrographs in
Fig. 2 shows the peculiar structure of moss leaves: the tissue is typically composed of a regular mosaic of chlorocysts and hyalocysts, with large pores that can act as a trapping system for airborne particulate (as passive samplers). The pores are irregular or ovalshaped with variable size from 5 to $15 \mu \mathrm{m}$. After 30-day exposure, abundant heterogeneous particles and minerals of nano- to micrometer size were found on the surface and inside the hyalocyst pores, and damage was visible in some of the external cell walls of the exposed mosses. Total collapse of the structure was found in the mosses exposed closest to the craters, due to the corrosive acid droplets directly derived from volcanic acid gases $\left(\mathrm{SO}_{2}, \mathrm{HCl}\right.$, $\mathrm{HF})$.

\subsection{Size and morphology of particles}

Particles with different features were observed on the walls and inside the pores of moss tissues, and they were classified in four different types of particles: (1) coarse and large particles $(\sim 2-$ $30 \mu \mathrm{m}$ ) of silicate composition, mainly angular shaped fragments (volcanic glass, lithics) and abundant crystals with regular habitus (e.g. gypsum, pyroxenes, feldspars, oxides); (2) sub-micron particles (less than $1 \mu \mathrm{m}$ in size), including fine anhedral fragments of silica and sulfate composition; (3) clusters $(\sim 0.5-5 \mu \mathrm{m})$ of incrustations and unshaped minerals (sulfates and/or halides), which were derived by condensation of acid volcanic vapours and droplets, often as agglomerates inside the pores of mosses; (4) polygenic particles $(\sim 10-30 \mu \mathrm{m})$, composed by a large silicate particle partially coated by condensed and/or sublimated sulfate and halide compounds. These observations are consistent with previous studies that recognized two main modes for fine (1$2 \mu \mathrm{m})$ and coarse $(7-10 \mu \mathrm{m})$ particles, by using different methodologies (aerosol spectrometer; plume sampling with mono or multistage cascade impactor) (Allen et al., 2006; Martin et al., 2008). In contrast with mosses highly exposed to volcanic emissions, particles collected at the urban site were mainly in the range of submicrometric size, with sporadic lithic fragments or minerals exceeding the $10 \mu \mathrm{m}$.

\subsection{Chemistry and mineralogy}

The X-ray microanalysis showed that the chemical composition of the particles is mostly defined by silicate (from pure silica to

Table 2

List of the particles recognized in this work by SEM/EDX observations. The size ranged from $<0.1$ to $>30 \mu \mathrm{m}$.

\begin{tabular}{|c|c|}
\hline Mineralogy & Chemistry \\
\hline Pure silica & $\mathrm{Si}-\mathrm{O}$ \\
\hline $\begin{array}{l}\text { Silicates (placioclases and } \\
\text { piroxenes) }\end{array}$ & $\begin{array}{l}\text { Al-Si-O; Fe-Al-Si-O; Mg-Al-Si-O; Mg-Fe-Al-Si-O; Mg-Ca-Al-Si-O; Mg-Ca-Fe-Al-Si-O; K-Al-Si-O; Na-Ca-Al-Si-O; Ca-Al- } \\
\text { Si-O }\end{array}$ \\
\hline Sulfates & Ca-S-O; Mg-S-O; Al-S-O; K-Al-S-O; K-Fe-S-O; Na-K-Fe-S-O; Na-K-Al-S-O; Fe-Al-S-O; S-Ca-Cu-O \\
\hline Chlorides & $\mathrm{Cl}-\mathrm{Na} ; \mathrm{Cl}-\mathrm{K} ; \mathrm{Cl}-\mathrm{Mg}$ \\
\hline Fluorides & $\mathrm{F}-\mathrm{Ca} ; \mathrm{F}-\mathrm{Al}-\mathrm{Fe} ; \mathrm{F}-\mathrm{Al} ; \mathrm{F}-\mathrm{Fe}$ \\
\hline Oxides & $\mathrm{Fe}-\mathrm{O} ; \mathrm{Fe}-\mathrm{Ti}-\mathrm{O}$ \\
\hline Polygenic particles & (silicates with incrustations of sulfo and halide salts) \\
\hline$?$ & $\mathrm{Fe}-\mathrm{Cr}$ \\
\hline
\end{tabular}


Table 3

Previous characterizations of volcanic particles (morphology, mineralogy and size) emitted from Mt. Etna.

\begin{tabular}{|c|c|c|c|c|c|c|}
\hline \multirow[t]{2}{*}{ Authors } & \multirow{2}{*}{$\begin{array}{l}\text { Sampling } \\
\text { location }^{\mathrm{a}}\end{array}$} & \multicolumn{2}{|l|}{ Methods } & \multicolumn{2}{|l|}{ Particles } & \multirow[t]{2}{*}{ Size $(\mu \mathrm{m})$} \\
\hline & & Sampling & Analisys & Mineralogy & Chemistry & \\
\hline \multirow[t]{3}{*}{ Lefevre et al. (1986) } & Inside the crater (BNC) & $\begin{array}{l}\text { Bulk filtration nuclepore } \\
\text { membrane } \\
0.4 \mu \mathrm{m} \text { flux } 1 \mathrm{~m}^{3} \mathrm{~h}^{-1} \text {, tot } 2-3 \mathrm{~m}^{3}\end{array}$ & TEM and SEM & $\mathrm{SiO}_{2}$ micsrospherules & $\mathrm{SiO}_{2}(47-98 \%)$ & $0.1-5$ \\
\hline & & & & Silicates (feldspars) & & \\
\hline & & & & $\begin{array}{l}\text { Sulfates } \\
\text { Oxides }\end{array}$ & & \\
\hline \multirow[t]{5}{*}{ Varekamp et al. (1986) } & $\begin{array}{l}\text { Fumaroles (SEC and NEC) and rim crater } \\
\text { (BNC) }\end{array}$ & $\begin{array}{l}\text { Bulk filtration two stage holder } \\
\text { nuclepore filter } 0.2 \mu \mathrm{m}\end{array}$ & SEM/EDS & Silicates & & \\
\hline & & & & (Al, Fe, Ca)-Sulfates & $\begin{array}{l}\mathrm{S}, \mathrm{Al}, \mathrm{Fe}, \mathrm{Ca}, \mathrm{Na}, \mathrm{Cu}, \mathrm{Zn} \\
\mathrm{Cd}, \mathrm{Ti}, \mathrm{Pb}\end{array}$ & $>10$ \\
\hline & & & & Oxides & $\mathrm{Fe}-\mathrm{O}$ & \\
\hline & & & & $\begin{array}{l}\text { Polygenic particles liquid droplets } \\
\text { (gaseous form?) }\end{array}$ & $\mathrm{H}_{2} \mathrm{SO}_{4}$ & $<0.5$ \\
\hline & & & & & $\mathrm{AlF}_{3}$ & \\
\hline \multirow[t]{4}{*}{ Andres et al. (1993) } & Rim crater (BNC and SEC) & $\begin{array}{l}\text { Selective Filtration Quartz } \\
\text { crystal microbalance cascade } \\
\text { impactor (QCM) nuclepore } \\
\text { membrane } 0.4 \mu \mathrm{m} \text { flux } 46 \text { to } \\
13.5 \mathrm{l} / \mathrm{min}\end{array}$ & SEM/EDX & Silica & $\mathrm{SiO}_{2}$ & $0.07->2$ \\
\hline & & & & $\begin{array}{l}\text { Silicates (plagioclase, augite, } \\
\text { complex silicates) }\end{array}$ & $\mathrm{MgSiO}_{3}$ & \\
\hline & & & & S-compounds & $\begin{array}{l}\mathrm{MgSO}_{4} ; \mathrm{K}_{2} \mathrm{SO}_{4} ; \mathrm{K}_{2} \mathrm{~S}_{2} \mathrm{O}_{7} ; \mathrm{Na}-\mathrm{S} ; \mathrm{K}-\mathrm{S} ; \\
\mathrm{Na}-\mathrm{K}-\mathrm{S} ; \mathrm{S} \text { dust }\end{array}$ & \\
\hline & & & & Cl-compounds & $\mathrm{KCl} ; \mathrm{NaCl} ; \mathrm{SiSCl} 2$ & \\
\hline \multirow[t]{3}{*}{ Toutain et al. (1995) } & Rim crater (BNC) & $\begin{array}{l}\text { Bulk filtration nuclepore filters } \\
0.4 \mu \mathrm{m} \text { flux } 1 \mathrm{~m}^{3} \text { ora }{ }^{-1} \text {, tot } 2- \\
3 \mathrm{~m}^{3}\end{array}$ & SEM/EDX-RF & Silicates and silica & & \\
\hline & & & & $\begin{array}{l}\text { Sulfates (thenardite, arcanite, } \\
\text { aphtitalite) }\end{array}$ & $\mathrm{Na}_{2} \mathrm{SO}_{4} ; \mathrm{K}_{2} \mathrm{SO}_{4} ; \mathrm{KNa}_{3}\left(\mathrm{SO}_{4}\right)_{2} ;$ rare $\mathrm{Cu}$ and $\mathrm{Zn}$ & \\
\hline & & & & $\begin{array}{l}\text { Chlorides (halite and silvite) } \\
\text { Oxides (iron oxide) }\end{array}$ & $\begin{array}{l}\mathrm{NaCl} ; \mathrm{KCl} \\
\mathrm{Fe}-\mathrm{O}\end{array}$ & \\
\hline \multirow[t]{4}{*}{ Martin et al. (2008) } & Rim crater (NEC and VOR) & $\begin{array}{l}\text { Selective filtration Micro-orifice } \\
\text { uniform deposition impactor } \\
\text { PTFE filters flux } 10 \mathrm{~L} \mathrm{~min}^{-1}\end{array}$ & QEMSCAN + EDX & Pure silica & $\mathrm{Si}-\mathrm{O}$ & $0.2-10$ \\
\hline & & & & Silicates (metal poor or rich) & $\begin{array}{l}\text { K-Al-Si-O; Ca-Na-Al-Si-O; Fe- } \\
\text { Al-Si-O; Ca-Al-Si-O; Mg-Fe-Al-Si-O; Mg- } \\
\text { Fe-Si-O }\end{array}$ & \\
\hline & & & & Sulfates & $\begin{array}{l}\mathrm{Ca}-\mathrm{S}-\mathrm{O} ; \mathrm{Al}-\mathrm{S}-\mathrm{O} ; \mathrm{Fe}-\mathrm{S}-\mathrm{O} ; \mathrm{Fe}-\mathrm{Al}-\mathrm{S}-\mathrm{O} ; \\
\mathrm{K}-\mathrm{S}-\mathrm{O} ; \mathrm{Na}-\mathrm{S}-\mathrm{O} ; \mathrm{Na}-\mathrm{K}-\mathrm{S}-\mathrm{O} ; \mathrm{Na}-\mathrm{Mg}-\end{array}$ & \\
\hline & & & & Sulfur/sulfides & $\begin{array}{l}\mathrm{Fe}-\mathrm{S}-\mathrm{O} \\
\mathrm{S} ; \mathrm{Fe}-\mathrm{S}\end{array}$ & \\
\hline
\end{tabular}

a Summit craters: NEC $=$ North East Crater; VOR = Voragine crater; $\mathrm{SEC}=$ South East Crater; BNC $=$ Bocca Nuova Crater 

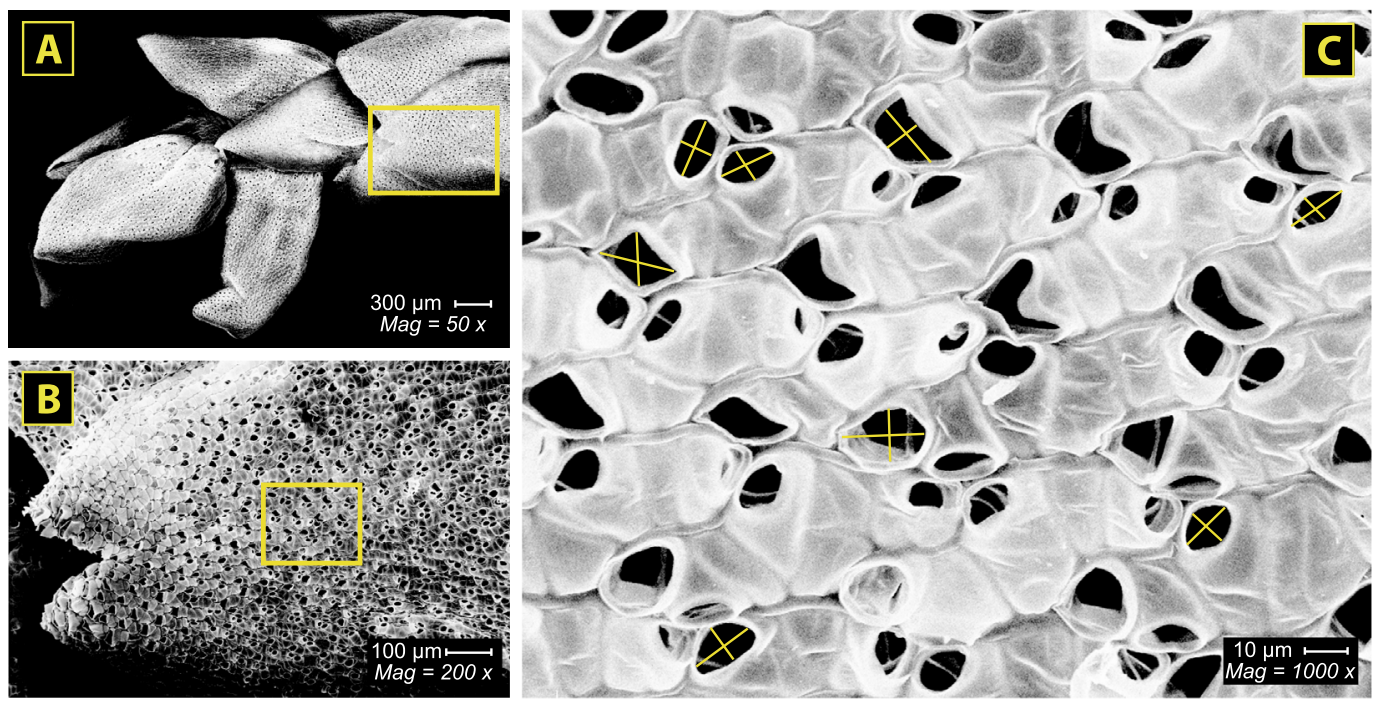

Fig. 2. Scanning electron microscopy (SEM) images of the unexposed Sphagnum (moss blank) shoot (a) and detail of the leaf tissues (b and c); Mag = magnification.

metal-rich silicate composition) and sulfate/halide compounds. The EDS analysis revealed that the major elements in the investigated particles include $\mathrm{Si}, \mathrm{Al}, \mathrm{Mg}, \mathrm{Fe}, \mathrm{K}, \mathrm{Ca}, \mathrm{Na}, \mathrm{S}, \mathrm{Cl}, \mathrm{F}$, and some trace elements like $\mathrm{Cu}, \mathrm{Cr}$ and $\mathrm{Ti}$. The abundance of particles in moss-bags was greater in down-wind sites located at shorter distances from the active vents $(0-5 \mathrm{~km})$, where the volcanogenic (erosive processes inside the craters, magma fragmentation, condensation and sublimation) and local geogenic (soil and volcanic ash re-suspension) sources are the major contributors of particulates. This is consistent with the exponential increase for most of the chemical concentrations found in the mosses after total microwave digestion (Calabrese et al., 2014). In particular, we found a systematic difference in abundance, size and mineralogy of particles collected in the different sampling sites. The most abundant particles on the upper part of the volcano, close to the craters (VOR and TDF), were sulfates and halide salts, along with silicate dominated particles. On the other hand, the chemical analyses did not evidence water-soluble salts at PLU site, close to the craters in up-wind location and poorly affected by plume fumigation. The particles collected in the urban site (CAT) were characterized by the mixing of different inputs, including sea salt aerosols, geogenic and anthropogenic dust.

\subsubsection{Sulfate and halide compounds}

At the site most exposed to volcanic emissions (VOR) a large amount of elongated-tabular crystals can be evidenced on the moss tissues, with sizes ranging from a few nanometres up to $15 \mu \mathrm{m}$. The largest crystals have a well-defined monocline/prismatic habitus and the EDS spectra of the crystals show peaks corresponding to sulfur (S), calcium (Ca) and oxygen $(\mathrm{O})$ confirming the identification as gypsum crystals (Fig. 3B). Similar spectra were obtained for many crystals in mosses exposed at more distant sites (TDF and CIT), up to $5 \mathrm{~km}$ from the craters (Figs. 4 and 5). Gypsum crystals are probably formed directly on the moss surface, through the reactions between droplets of sulfuric acid, deriving from the oxidation of $\mathrm{SO}_{2}$, and the calcium-rich tissue of mosses. Varekamp et al. (1986) previously reported the presence of abundant sulfuric acid droplets in the Etnean plum. However, the relatively low crystallisation kinetic did not allow the sulfate crystal formation on the mosses exposed only for one day at the same site, despite of having accumulated a conspicuous amount of sulfur (Calabrese et al., 2014). Furthermore, the absence of sulfate crystals on the moss-bag exposed only for one day excludes the possibility that the euhedral crystals could have been formed within the plume. Although sulfur has been detected in the Etnean plume emissions in the particulate phase (Aiuppa et al., 2003), representing on average 6\% of the total plume sulfur emission, euhedral sulfate crystals has never been detected. Martin et al. (2008) have recognized a considerable increase in sulfates particles in both plumes (NEC and VOR) with respect to the background. Chemical analyses of the size-resolved particles showed bimodal peaks in sulfates at $\sim 1$ and $\sim 8 \mu \mathrm{m}$ from NEC samples and, in contrast, only a unimodal peak $(\sim 1 \mu \mathrm{m})$ from VOR crater, highlighting the difference between the emissions of both active craters. However, also the study of Martin et al. (2008) failed in identifying well-crystallised sulfate phases within the Etnean volcanic plume, even whit the use of automated scanning electron microscopy (QEMSCAN) for the analysis of the size, shape and composition of thousands of particles on each filter.

In the present study, in addition to gypsum crystals, frequent $\mathrm{Al}$ and Fe sulfates were observed as clusters inside the hyalocyst pores and as overgrowth incrustations over silicate fragments. The formation of such sulfates is typical of highly acid and oxidizing environments. They are found, for example, as efflorescences and incrustations either in areas characterized by the presence of sulfide ores (Jambor et al., 2000) or by volcanic/geothermal activity (Rodgers et al., 2000). Their formation is driven by the presence of abundant sulfuric acid generally deriving from the oxidation of the sulfide minerals in the former case and of hydrogen sulfide in the latter. In the present case the sulfuric acid necessary to the formation of the $\mathrm{Al}$ and $\mathrm{Fe}$ sulfates derives from the oxidation of the $\mathrm{SO}_{2}$ emitted by the Etnean plume and, like for gypsum, the corresponding cation derives either from the moss itself or from the silicate particles (e.g. plagioclases or pyroxenes) on which the crystals have grown. The EDS analyses did not allow defining precise phases, also because of the big number of possible mineralogical phases, often differing only by the hydration state. For example, ferrous iron sulfate can be found as $\mathrm{FeSO}_{4} \cdot \mathrm{nH}_{2} \mathrm{O}$ with $n=1,4,5$ or 7 (Jambor et al., 2000). Environments where $\mathrm{Al}$ and Fe sulfate minerals are found allow also the formation of sulfate minerals in which the main cations are trace metals like $\mathrm{Ba}, \mathrm{Cu}, \mathrm{Mn}, \mathrm{Ni}, \mathrm{Pb}$ and others (Kyriakopoulos et al., 1990). In the present study no trace metal rich sulfate phases have been identified. However, as identified through EDS spectrum, sulfate crystals can, sometimes, include trace elements like $\mathrm{Cu}$ (Fig. 5) or $\mathrm{Pb}$, highlighting their important role in transporting available trace metals at long distances. 

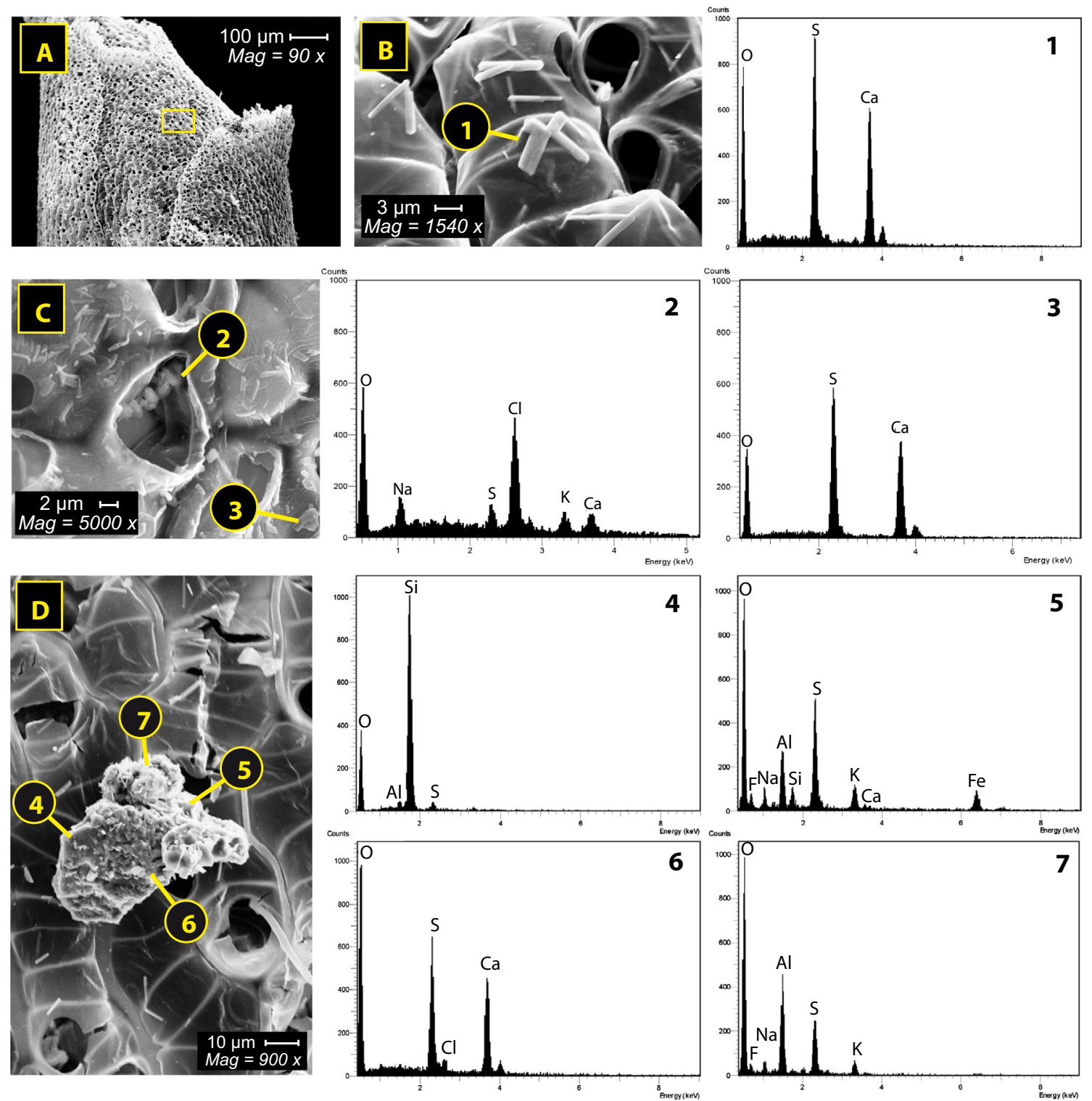

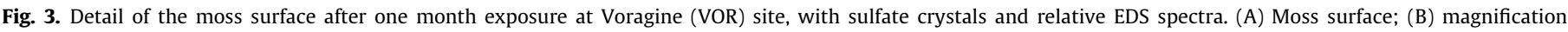

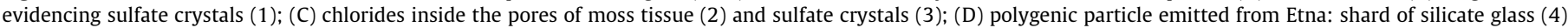
with overgrowth soluble salts (5-7) onto the surface.

Chloride compounds were rarely observed at the summit sites, mainly as incrustations and as clusters of micrometric and submicrometric crystals inside the hyalocyst pores (Fig. 3C), or overgrowth onto pre-existing particles (Fig. 3D). The EDS spectra highlighted that the dominant chemical composition of hygroscopic salts is $\mathrm{Na}$ and $\mathrm{K}$ chlorides, resulting from sublimation or crystallization of $\mathrm{Cl}$-saturated vapours or liquid, respectively. The following reaction, proposed by Erikson (1960), hypothesizes the formation of gaseous $\mathrm{HCl}$ from the sulfuric acid droplets and metal-chlorides:

$2 \mathrm{XCl}_{\text {(solid) }}+\mathrm{H}_{2} \mathrm{SO}_{4 \text { (liquid) }} \leftrightarrow \mathrm{X}_{2} \mathrm{SO}_{4 \text { (solid) }}+2 \mathrm{HCl}_{\text {(gas) }}$

This is consistent with our results and it could explain the lack of chloride salts on mosses. Previous results from Varekamp et al. (1986) highlighted the absence of hydrochloric acid droplets in the Etna plume. Even Andres et al. (1993) have concluded that most of the $\mathrm{Cl}$ emitted from BNC and SEC craters was in a gaseous or small aerosol $(<0.4 \mu \mathrm{m})$ form. These founding are also consistent with the results reported by Martin et al. (2008) that in the detailed study of particulate from Etna did not find chloride salts. Moreover, leaching experiment of moss-bags (Calabrese et al.,
2014) showed that chlorine was depleted probably due to the revolatilization of alkali chlorides during the field exposure, in contrast with sulfur and fluorine, strongly enriched in the moss-bags close to the active vents.

Fluoride compounds were mostly found as incrustations and coating patinas on pre-existing particles (Fig. 3D). The anhedral mineralogical assemblage of $\mathrm{F}-\mathrm{Ca}, \mathrm{F}-\mathrm{Al}$ and $\mathrm{F}-\mathrm{Fe}$ in agglomerates and incrustations are very common. The association of $\mathrm{F}$ with $\mathrm{Al}$ and Fe sulfates highlights the fundamental role of fluoride in the vapor transport of refractory metals, as already been suggested by previous authors (Rose et al., 1982; Varekamp et al., 1986; Delmelle et al., 2002; Martin et al., 2008). This would easily explain also the strong positive relation between the fluoride concentrations and the numerous refractory elements (e.g. Al, Fe, Ti) found in rainwaters collected on Mount Etna close to the summit craters (Calabrese et al., 2011).

\subsubsection{Silicates, oxides and polygenic particles}

Other common particles in down-wind sites exposed to volcanic deposition include: angular to sub-angular silicate compounds; 

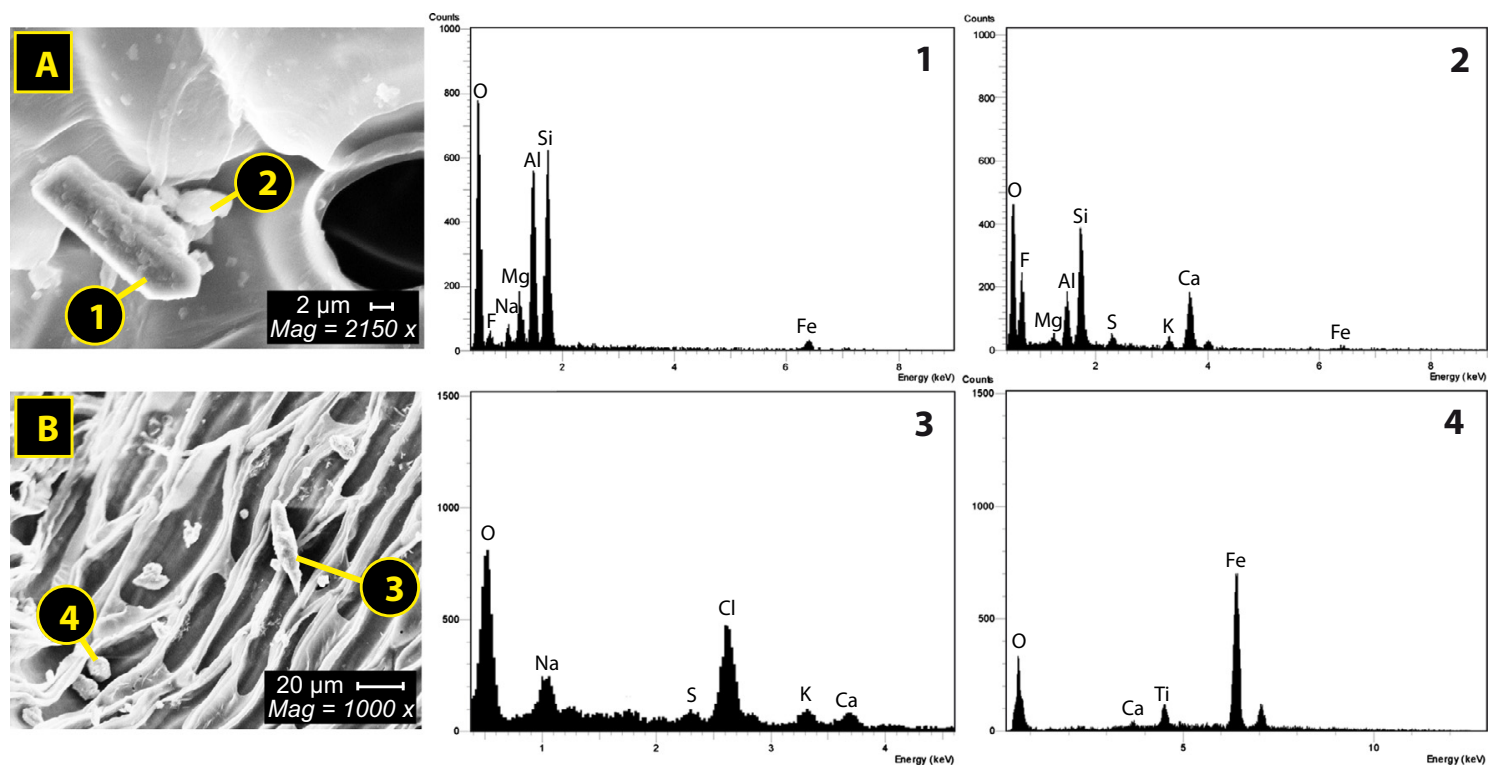

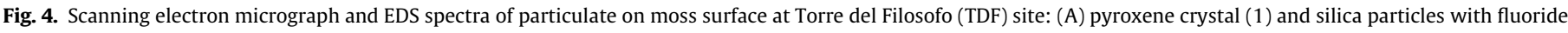
incrustations (2); (B) amorphous Halite (3) and iron oxide (4) particles.
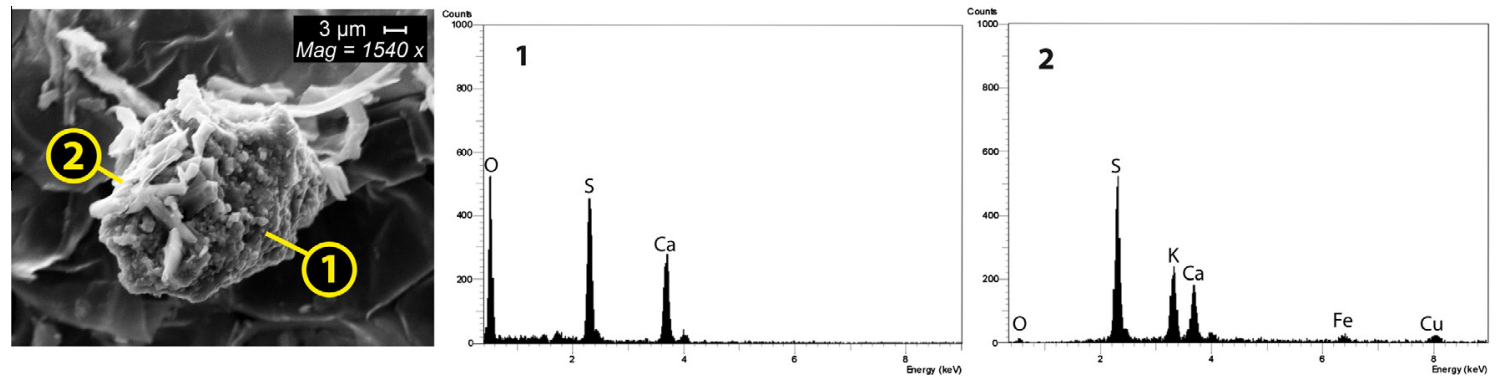

Fig. 5. Polygenic particle with incrustations and crystals of metal-rich sulfur compounds at CIT site.
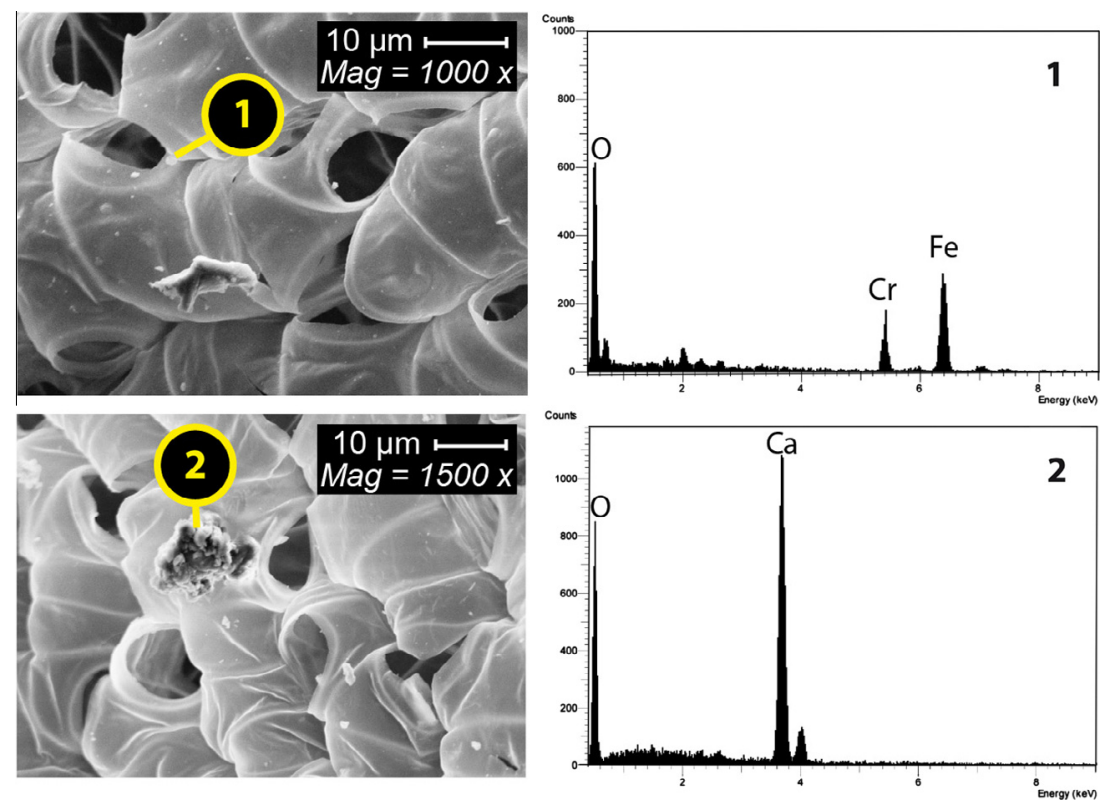

Fig. 6. Non-volcanic particulates: (1) submicron $\mathrm{Cr}$-Fe particle at urban site (CAT 2) and (2) geogenic carbonate particle (INT site). 
shard of silicate glass and lithics; fragment of minerals (e.g. pyroxene in Fig. 4A); oxides (e.g. titanium magnetite in Fig. 4B). We recognized a large number of silicate particles ranging from coarse $(2-30 \mu \mathrm{m})$ to fine particles $(0.1-2 \mu \mathrm{m})$, in the upper part of the volcano close to the active craters. According with previous interpretations, the former are mainly mechanically generated (erosive processes or magma fragmentation), the latter are primary particles and/or aggregates generated by chemical and physical reactions (e.g. condensation, sublimation, oxidations) within the volcanic plume. Of particular interest are the numerous silicates particles with agglomerates and incrustations of soluble salts (sulfate and halides) overgrown onto their surface. These polygenic particles testify overgrowing processes that occur inside the plume when, decreasing temperature during ascent in the conduit, inducing gas-liquid-solid reactions lead to the formation and deposition of salts on the surface of pre-existent particles (volcanic glass or wall-conduit erosive fragments). These particles originating from primary volcanic source are characterized mainly by large angular fragments with a silicate chemical composition, have variable size from few up to $15 \mu \mathrm{m}$, and were frequently found in mosses exposed close to the craters and, sporadically, also some kilometres away from the active vents (e.g. CIT site, $6 \mathrm{~km}$ from the craters in downwind direction - Fig. 5).

\subsubsection{Non-volcanic particles}

In general, carbonate particles of regional geogenic dust were frequently found both in distal and closer sites with respect to the active vents, and both in downwind and upwind sectors of the volcano edifice. These particles are in the range from 2 to $10 \mu \mathrm{m}$ are related to local and/or regional input (Fig. 6).

The moss-bag exposed in Catania town (CAT 2) showed a marked differences in chemistry and morphology of particulate: their size range from tens of nanometres to less than $2-3 \mu \mathrm{m}$ with no well-defined shape, except for occasional altered fragments of silicate minerals (Fig. 6); some not well-shaped particles of sodium chloride $(\mathrm{NaCl})$ were also found, and are referable to the marine spray input due to the closeness of the town to the Ionian Sea coast. A marine spray input has been also evidenced by the chemical analysis of the moss-bags, specifically by the increase in B content with respect to not exposed moss-bags (Calabrese et al., 2014). The smaller particles collected in the urban site also included unidentified $\mathrm{Fe}-\mathrm{Cr}$ compounds (Fig. 6), probably referable to anthropogenic input.

\section{Conclusions}

The application of moss-bags technique in the active volcanic area of Mount Etna allowed to characterize volcanogenic particles continuously emitted from the active craters. Although the technique does not allow to obtain quantitative results, this study confirms the suitability of active biomonitoring as a low-cost and robust technique to investigate chemistry, morphology and mineralogy of particulates in active volcanic/hydrothermal environments. Our results confirmed the huge amount of silicates, sulfates and halides compounds emitted into the atmosphere from Mount Etna, greatly influencing the deposition in the surrounding area. Moreover, the careful study of the particles trapped in the moss, has allowed us to interpret their complex history and formation mechanism. Besides the volcanic input, we identified the local atmospheric background, mainly dominated by local/regional geogenic input, a marine-aerosol contribution from the nearby Ionian Sea and local anthropogenic sources. However, further studies are needed to standardize and implement the use of moss-bags in regular biomonitoring programs and to support the conventional techniques of volcanic aerosols sampling.

\section{Acknowledgments}

The authors are very grateful to Jonas Somar that picked up the mosses in Sweden, paving the way for this study. We wish to thank Franco Furnari for its precious laboratory assistance during SEMEDS analysis, Angela Ribaudo and Francesca Catania for their enthusiasm and useful support in the laboratory.

\section{References}

Adamo, P., Crisafulli, P., Giordano, S., Minganti, V., Modenesi, P., Monaci, F., Pittao, E., Tretiach, M., Bargagli, R., 2007. Lichen and moss bags as monitoring device in urban areas. Part II: Trace element content in living and dead biomonitors and comparison with synthetic materials. Environ. Pollut. 146, 392-399.

Aiuppa, A., Dongarrà, G., Valenza, M., Federico, C., Pecoraino, G., 2003. Degassing of trace volatile metals during the 2001 eruption of Etna. In: Robock A, Oppenheimer, C. (Eds.), Volcanism and the Earth's Atmosphere. AGU Geophys. Monogr., vol. 139, pp. 41-54.

Aiuppa, A., Bellomo, S., Brusca, L., D’Alessandro, W., Di Paola, R., Longo, M., 2006. Major-ion bulk deposition around an active volcano (Mt. Etna, Italy). Bull. Volcanol. 68, 255-265.

Aiuppa, A., Giudice, G., Gurrieri, S., Liuzzo, M., Burton, M., Caltabiano, T., McGonigle, A.J.S., Salerno, G., Shinohara, H., Valenza, M., 2008. Total volatile flux from Mount Etna. Geophys. Res. Lett. 35, L24302. http://dx.doi.org/10.1029/ 2008GL035871.

Allen, A.G., Mather, T.A., McGonigle, A.J.S., Aiuppa, A., Delmelle, P., Davison, B., Bobrowski, N., Oppenheimer, C., Pyle, D.M., Inguaggiato, S., 2006. Sources, size distribution, and downwind grounding of aerosols from Mount Etna. J. Geophys. Res. 111, D10302. http://dx.doi.org/10.1029/2005JD006015.

Andres, R.J., Kyle, P.R., Chuan, R.L., 1993. Sulphur dioxide, particle and elemental emissions from Mount Etna, Italy during July 1987. Geol. Rundsch. 82, 687-695.

Arndt, J., Calabrese, S., D'Alessandro, W., Planer-Friedrich, B., 2014. Active moss monitoring allows to identify and track distribution of metal(loid)s emitted from fumaroles on Vulcano Island, Italy. J. Volcanol. Geotherm. Res. 280, 30-39. http://dx.doi.org/10.1016/j.jvolgeores.2014.04.016.

Calabrese, S., Aiuppa, A., Allard, P., Bagnato, E., Bellomo, S., Brusca, L., D’Alessandro, W., Parello, F., 2011. Atmospheric sources and sinks of volcanogenic elements in a basaltic volcano (Etna, Italy). Geochim. et Cosmochim. Acta 75 (23), 74017425. http://dx.doi.org/10.1016/j.gca.2011.09.040.

Calabrese, S., D’Alessandro, W., Bellomo, S., Brusca, L., Martin, R.S., Parello, F., 2014. Characterization of the Etna volcanic emissions through an active biomonitoring technique (moss-bags): Part 1 - Major and trace element composition. Chemosphere. http://dx.doi.org/10.1016/j.chemosphere.2014.08. 086.

Caltabiano, T., Burton, M., Giammanco, S., Allard, P., Bruno, N., Murè, F., Romano, R., 2004. Volcanic gas emissions from the summit craters and flanks of Mt. Etna, 1987-2000. In: Bonaccorso, A., Calvari, S., Coltelli, M., Del Negro, C., Falsaperla, S. (Eds.), Etna Volcano Laboratory: AGU Geophysical Monography Series, vol. 143, pp. 111-128.

Chin, M., Jacob, D.J., 1996. Anthropogenic and natural contributions to tropospheric sulfate: a global model analysis. J. Geophys. Res. 101, 18691-18699.

D'Alessandro, W.. Giammanco, S., Parello, F. Valenza, M., 1997. CO 2 output and ${ }^{13} \mathrm{C}\left(\mathrm{CO}_{2}\right)$ from Mount Etna as indicators of degassing of shallow asthenosphere. Bull. Volcanol. 58, 455-458.

Delmelle, P., 2003. Environmental impacts of tropospheric volcanic gas plumes. In: Oppenheimer, C., Pyle, D.M., Barclay, J. (Eds.), Volcanic Degassing. Special Publications, vol. 213. Geological Society of London, pp. 381-399.

Delmelle, P., Stix, J., Baxter, P.J., Garcia-Alvarez, J., Barquero, J., 2002. Atmospheric dispersion, environmental effects and potential health hazard associated with the low-altitude gas plume of Masaya volcano, Nicaragua. Bull. Volcanol. 64, 423-434. http://dx.doi.org/10.1007/s00445-002-0221-6.

Erikson, E., 1960. The yearly circulation of chloride and sulfur in nature: meteorological, geochemical and pedological implications, 2. Tellus 12, 63-109.

Gauthier, P.J., Le Cloarec, M.F., 1998. Variability of alkali and heavy metal fluxes released by Mt. Etna volcano, Sicily, between 1991 and 1995. J. Volcanol. Geoth. Res. 81, 311-326.

Graf, H.-F., Langmann, B., Feichter, J., 1998. The contribution of Earth degassing to the atmospheric sulphur budget. Chem. Geol. 147, 131-145.

Jambor, J.L., Nordstrom, D.K., Alpers, C.N., 2000. Metal-sulfate salts from sulfide mineral oxidation. In: Alpers, C.N., Jambor, J.L., Nordstrom, D.K. (Eds.) Sulfate Minerals: Crystallography, Geochemistry, and Environmental Significance. Reviews in Mineralogy and Geochemistry, vol. 40, pp. 303-350.

Kyriakopoulos, K., Kanakis-Sotiriou, R. Stamatakis, M.G., 1990. The authigenic minerals formed from volcanic emanations at Soussaki, W. Attica peninsula, Greece. Can. Mineral. 28, 363-368.

Lefevre, R., Gaudichet, A., Billongalland, M.A., 1986. Silicate microspherules intercepted in the plume of Etna volcano. Nature 322, 817-820. http:// dx.doi.org/10.1038/322817a0.

Martin, R.S., Mather, T.A., Pyle, D.M., Power, M., Allen, A.G., Aiuppa, A., Horwell, C.J., Ward, E.P.W., 2008. Composition-resolved size distributions of volcanic aerosols in the Mt. Etna plumes. J. Geophys. Res. 113, D17211. http:// dx.doi.org/10.1029/2007JD009648. 
Martin, R.S., Mather, T.A., Pyle, D.M., Watt, S.F.L., Day, J., Collins, S.J., Wright, T.E., Aiuppa, A., Calabrese, S., 2009. Sweet chestnut (Castanea sativa) leaves as a bioindicator of volcanic gas, aerosol and ash deposition onto the flanks of Mt. Etna in 2005-2007. J. Volcanol. Geoth. Res. 179, 107-119. http://dx.doi.org/10.1016/ j.jvolgeores.2008.10.012.

Martin, R.S., Witt, M.L.I., Sawyer, G.M., Thomas, H.E., Watt, S.F.L., Bagnato, E., Calabrese, S., Aiuppa, A., Delmelle, P., Pyle, D.M., Mather, T.A., 2012. Bioindication of volcanic mercury $(\mathrm{Hg})$ deposition around Mt. Etna (Sicily). Chem. Geol. 310-311, 12-22. http://dx.doi.org/10.1016/j.chemgeo.2012.03.022.

Notcutt, G., Davies, F., 1989. Accumulation of volcanogenic fluoride by vegetation: Mt. Etna, Sicily. J. Volcanol. Geoth. Res. 39, 329-333.

Quayle, B.M. Mather, T.A. Witt, T.A. Maher, B.A. Mitchell, R. Martin, R.S. Calabrese, S., 2010. Application and evaluation of biomagnetic and biochemical monitoring of the dispersion and deposition of volcanicallyderived particles at Mt. Etna, Italy. J. Volcanol. Geoth. Res. 191, 107-116.

Rodgers, K.A., Hamlin, K.A., Browne, P.R.L., Campbell, K.A., Martin, R., 2000. The steam condensate alteration mineralogy of Ruatapu cave, Orakei Korako

geothermal field, Taupo Volcanic Zone, New Zealand. Mineral. Mag. 64, 125142.

Rose, W.I., Chuan, R.L., Woods, D.C., 1982. Small particles in plumes of Mount St. Helens. J. Geophys. Res. 87, 4956-4962.

Sekine, Y. Sakajiri, K., Kikuchi, E., Matsukata, M., 2008. Release behavior of trace elements from coal during high-temperature processing. Powder Technol. 180, 210-215. http://dx.doi.org/10.1016/j.powtec.2007.03.012.

Toutain, J.P., Quisefit, J.P., Briole, P., Aloupogiannis, P., Blanc, P., Robaye, G., 1995. Mineralogy and chemistry of solid aerosols emitted from Mount Etna. Geochem. J. 29, 163-173.

Tretiach, M., Adamo, P., Bargagli, R., Baruffo, L., Carletti, L., Crisafulli, P., et al., 2007 Lichen and moss-bags as monitoring devices in urban areas. Part I: Influence of exposure on sample vitality. Environ. Pollut. 146, 380-391.

Varekamp, J.C., Thomas, E., Germani, M., Buseck, P.R., 1986. Particle geochemistry of volcanic plumes of Etna and Mount St. Helens. J. Geophys. Res. 91, 12233 12248 . 